\title{
Súmula vinculante inconstitucional: forma de controle de constitucionalidade e crise de legitimidade
}

\author{
Unconstitutional súmula vinculante: constitutional control and crisis of legitimacy
}

Rosemiro dos Reis Martins ${ }^{1}$

\section{Resumo}

Este artigo versa sobre o instituto da Súmula Vinculante, analisando seus requisitos de elaboração, os quais estão previstos tanto na Constituição Federal quanto na Lei n. 11.471/2006, sua natureza jurídica, assim como a possibilidade de elaboração de súmulas de efeito vinculante inconstitucionais pelo Supremo Tribunal Federal. Trata também do desenvolvimento histórico da súmula de efeito vinculante, principalmente no direito brasileiro; além de propor formas de impugnar súmulas vinculantes de conteúdo inconstitucional. Define-se em que ponto haveria invasão de competências e falta de legitimidade do Poder Judiciário ao utilizar a súmula de efeito vinculante para legislar, frente à possibilidade da ocorrência de súmulas materialmente e formalmente inconstitucionais e ao princípio da separação de poderes.

Palavras-chave: Súmula Vinculante; Supremo Tribunal Federal; Inconstitucional; Legitimidade.

\section{Abstract}

This article focuses on the institution of Súmula Vinculante, reviewing their requirements for creation, which are provided for both in the Federal Constitution and in Law n. 11.471/2006, its legal status, as well as the possibility to be produced by the Supreme Court unconstitucional precedents of binding efect. The historical development of the súmula vinculante its also analised, mainly in brazilian law, and are proposed ways to impugn unconstitucional content of binding precedents. It defines at what point would happen the invasion of skills and lack of legitimacy of the Judiciary when use the sum of the binding effect to legislate, considering the possible occurrence of materially and formally unconstitutional precedents and the principle of separation of powers.

Keywords: Binding precedents; Supreme Court; Unconstitucional; Legitimacy.

1 Bacharel em Direito pela Universidade Estadual de Maringá (UEM). Especialista em Direito Constitucional pela Universidade Estadual de Maringá (UEM). Analista Judiciário (Especialidade Área Judiciária) do Tribunal de Justiça do Estado Paraná (TJPR). 


\section{Introdução}

A súmula de efeito vinculante foi introduzida no ordenamento jurídico brasileiro pela Emenda Constitucional (EC) n. 45/2004, norma de eficácia limitada, cujo complemento veio a lume com a Lei $n$. 11.417/2006.

A partir da EC n. 45/04, as decisões do Supremo Tribunal Federal (STF) passam a gozar de eficácia erga omnes e efeito vinculante, tanto em sede de controle concentrado de constitucionalidade, quanto no âmbito do controle difuso de constitucionalidade.

Com o advento da Súmula Vinculante, o STF está habilitado a fazer com que as decisões tomadas em ações individuais, de eficácia inter partes, transcendam estes limites e se elevem ao patamar da abstração, lançando seus efeitos, por sua vez, sobre outros casos idênticos.

Com a alteração constitucional acima referida foi garantida eficácia erga omnes e efeito vinculante não só à Ação Declaratória de Constitucionalidade (ADC), que já possuía esses atributos, mas também à Ação Direta de Inconstitucionalidade (ADI), a qual passa a se equiparar, no plano constitucional, em efeitos àquela. Assim, pode-se afirmar que doravante aqueles efeitos serão naturais das decisões de controle concentrado de constitucionalidade, os quais, sem dúvida, poderão ser modulados para adequarem-se às colorações do caso específico.

Por sua vez, no controle difuso de constitucionalidade, a eficácia erga omnes e o efeito vinculante não serão decorrências naturais de uma decisão do STF em um caso pontual; para adquirirem seus plenos efeitos, estas decisões dependerão da iniciativa dos ministros do Pretório Excelso para a elaboração de uma súmula de efeito vinculante, ou da iniciativa de um dos co-legitimados previstos no $\S 22^{\circ}$, do art. 103-A, da Lei Maior, cujo rol foi ampliado pela Lei n. $11.417 / 2006$, os quais poderão sugerir a criação de uma súmula ao Pretório Excelso.

No que toca à iniciativa para a edição, revisão e cancelamento de súmula vinculante, tem-se como legitimados: a) o STF, que tem a faculdade de promover-lhes a edição, revisá-las e cancelá-las de ofício, e; b) os legitimados para propor ADI, os quais estão listados no art. 103, caput e incisos, da Constituição Federal, além daqueles outros legitimados habilitados pela Lei $n$. 11.417/2006. Importante notar que foram acrescentados outros legitimados não previstos na CF/88 pela referida norma infraconstitucional, quais 
sejam: o Defensor Público-Geral da União; os Tribunais Superiores; os Tribunais de Justiça dos Estados ou Distrito Federal e Territórios; os Tribunais Regionais Federais; os Tribunais Regionais do Trabalho; os Tribunais Regionais Eleitorais e, por fim, os Tribunais Militares.

Assim, os legitimados são: o STF; o Presidente da República; a Mesa do Senado Federal; a Mesa da Câmara dos Deputados; a Mesa das Assembleias Legislativas Estaduais; a Câmara Legislativa do Distrito Federal (DF); o Governador de Estado ou do Distrito Federal; o Procurador-Geral da República; o Conselho Federal da Ordem dos Advogados do Brasil (OAB); Partido Político com representação no Congresso Nacional; Confederação Sindical ou Entidade de Classe de Âmbito Nacional; Defensor Público-Geral da União; os Tribunais Superiores, os Tribunais de Justiça dos Estados ou Distrito Federal e Territórios; os Tribunais Regionais Federais; os Tribunais Regionais do Trabalho; os Tribunais Regionais Eleitorais e os Tribunais Militares.

Neste ponto, data maxima venia, segundo nosso entendimento, é cabível a mesma distinção feita em relação aos legitimados para propor a ADI, dividindo-os em legitimados universais e legitimados especiais, estes atrelados à pertinência temática quando da propositura de matéria a ser sumulada.

São denominados legitimados universais para propor edição, revisão e cancelamento de Súmula Vinculante:
a) STF;
b) Presidente da República;
c) Mesa do Senado Federal;
d) Mesa da Câmara dos Deputados;
e) Procurador-Geral da República;
f) Conselho Federal da Ordem dos Advogados do Brasil;
g) Partido Político com representação no Congresso Nacional;
h) Defensor Público-Geral da União.

Por sua vez, são denominados legitimados especiais:

\footnotetext{
a) Mesa das Assembleias Legislativas Estaduais;

b) Câmara Legislativa do Distrito Federal (DF);

c) Governador de Estado ou do Distrito Federal;

d) Confederação Sindical ou Entidade de Classe de Âmbito Nacional;

e) Tribunais Superiores, os Tribunais de Justiça dos Estados ou Distrito Federal e Territórios; os Tribunais Regionais Federais; os Tribunais Regionais do Trabalho; os Tribunais Regionais Eleitorais e, por fim, os Tribunais Militares.
} 
A grande característica do instituto analisado é sua força vinculante, haja vista que as súmulas editadas terão o poder de direcionar e conformar as decisões dos órgãos do Poder Judiciário e da Administração Pública direta e indireta, nas esferas federal, estadual e municipal, exceto as decisões do STF.

O objeto da súmula é a lei lato sensu, ou seja, leis e atos normativos, no que tange à questão constitucional. Neste aspecto assevera André Ramos Tavares, in verbis:

O alcance conferido à realização da súmula foi impressionante, extrapolando a mera validade e interpretação da Constituição e das leis (em face da Constituição) para alcançar a eficácia de 'atos normativos'. Para ficar mais claro: acresceu-se a possibilidade de (i) dispor sobre eficácia, e (ii) ter como objeto qualquer ato normativo, e não apenas a lei ou a Constituição. (TAVARES, 2009, p. 41)

Ainda nesta esteira, André Ramos Tavares (2009, p. 41) afirma que a súmula poderá tratar de normas federais, estaduais, distritais ou municipais, desde que as mesmas não versem exclusivamente sobre matéria infraconstitucional.

\section{Súmula Vinculante: requisitos}

A elaboração de uma súmula vinculante exige que estejam presentes todos os pressupostos e requisitos previstos pela Constituição Federal (CF), por isso a delimitação dos mesmos é necessária para aferir sua validade e eficácia jurídica.

Assim, pode-se afirmar que são pressupostos fáticos para lastrear a proposta de edição de uma súmula vinculante: a existência de controvérsia atual sobre a validade, interpretação ou eficácia de lei e a relevante multiplicação de processos sobre o tema constitucional controverso.

São requisitos para a aprovação da súmula acima referida: existência de decisões uniformes e reiteradas versando sobre determinado tema constitucional objeto de lei; o exercício da iniciativa de criação por um dos legitimados do art. 103-A, § 3ำ c/c art. 103, caput, ambos da Constituição Federal, e art. 3o da Lei n. 11.417/2006; concordância na edição da súmula vinculante, pelo voto, de dois terços (2/3) dos Ministros do STF; publicação na imprensa oficial.

A doutrina sustenta, com acerto, que são objetivos gerais do instituto analisado: a segurança jurídica (art. 5으, caput, da CF/88) e a celeridade processual (art. 5으, LXXVIII, 
CF/88). Ao passo que são objetivos específicos do mesmo: avaliar a validade das leis; fixar interpretação constitucional das leis (uniformização de jurisprudência); decidir acerca da eficácia jurídica de normas determinadas - normas de eficácia plena, contida ou limitada, conforme a classificação de José Afonso da Silva (2009, p. 82-83).

De pronto, já se pode afirmar com certeza que a súmula vinculante não deve impedir o acesso dos jurisdicionados à Justiça (art. 50, XXXV, CF/88), mas, sim, possibilitar que processos de mesma natureza (ações idênticas com autores diversos) sejam resolvidos de forma uniforme e célere, trazendo, por sua vez, credibilidade à atuação pacificadora do Poder Judiciário. Trilhando este caminho, o Pretório Excelso manter-se-á dentro dos limites da constitucionalidade, evitando-se, por conseguinte, a usurpação de funções de um Poder por outro, ou seja, o STF não poderá, portanto, legislar.

\section{Origem histórica da Súmula Vinculante}

A origem histórica da súmula de efeito vinculante está atrelada aos editos dos magistrados judiciários do Império Romano, assim como aos assentos do Direito Português, de onde nosso Direito se originou, haja vista a influência marcante da colonização portuguesa em nosso País.

Todavia, no Brasil a súmula teve início como súmula persuasiva, promovida no âmbito do STF pelo Ministro Vitor Nunes Leal, a qual tinha como razões para a sua implementação a necessidade do estabelecimento de um método de trabalho efetivo; a promoção dos princípios da segurança jurídica e da igualdade entre os jurisdicionados, o argumento segundo o qual casos iguais deveriam receber soluções iguais; e a tentativa de inibir recursos protelatórios, através da publicidade dos posicionamentos do Pretório Excelso (LOR, 2009, p. 18).

Não se pode olvidar, também, que Alfredo Buzaid, relator do anteprojeto do Código de Processo Civil (CPC) de 1973, intentou criar um instituto semelhante à atual súmula vinculante no referido Estatuto Legal, o qual seria o produto imediato do Incidente de Uniformização da Jurisprudência (arts. 476 até 479 do CPC) atualmente previsto no CPC, porém não obteve sucesso, haja vista que a novidade legislativa foi barrada no Congresso Nacional. Quanto a estes acontecimentos nos informa Encarnacion Alfonso Lor, veja-se: 
Muito embora contasse com o apoio de parte majoritária da doutrina, a proposta de Alfredo Buzaid foi suprimida do anteprojeto, posto que rejeitada pela Comissão Revisora do Congresso Nacional, sob a fundamentação de afronta constitucional aos princípios da independência jurisdicional e da separação dos poderes. A idéia, contudo, não resultou de todo sem proveito, inspirando o Ministro Victor Nunes Leal para a criação das súmulas do Supremo Tribunal Federal. (LOR, 2009, p. 32).

Independentemente desta digressão histórica, percebe-se, também, que o instituto analisado resulta da aproximação que vem ocorrendo entre dois sistemas jurídicos atualmente diversos, porém de origem remota comum, quais sejam: o common law, de vertente anglo-americana, e o civil law, da vertente do direito romano-germânico.

Neste sentido tem-se Flávio Luís Oliveira e Nilson Tadeu Reis Campos Silva, os quais defendem uma origem comum para esses dois sistemas jurídicos, cuja gestação, ao que tudo indica, ocorreu no seio do Direito Romano:

Contudo, o que nos interessa aqui é demonstrar as similitudes desses dois grupos, para enfatizar a crescente e necessária reaproximação diatópica de ambos, o que é possível porque o código genético dos dois grupos é idêntico, gestados que foram pelo Direito Romano, ainda que em épocas diversas: na época do direito romano clássico, predominava a argumentação e a interpretação para a solução dos conflitos - tal como sucede com a família da common law, enquanto que a da civil law inegavelmente é fruto da fase do direito romano imperial, legalista e codificado. (OLIVEIRA; SILVA, 2009, p. 64).

Assim, a diferença entre esses dois sistemas jurídicos não está ligada à origem, mas, sim, a questões históricas e filosóficas. No que tange à questão histórica, verifica-se que o civil law deriva da influência francesa sobre o continente europeu, principalmente em razão da Revolução Francesa de 1789, quando a monarquia absolutista foi derrubada e em seu lugar surgiu o império da lei (positivismo), haja vista que os juízes da época foram em grande parte adversários das mudanças políticas estruturais, figurando, por sua vez, como representantes de um regime de opressão e privilégios.

A desconfiança em relação aos juízes da época e a necessidade de limitar-lhes a autonomia os levaram a assumir, no cenário político então vigente, a posição de a "boca da lei", nas palavras de Montesquieu (2007, p. 167-169).

Por outro lado, nos países do common law não houve esse rompimento traumático com governos anteriores, pelo menos não a ponto de ser necessário delimitar a autonomia dos juízes pela lei; por isso os magistrados puderam trilhar pelo caminho da aplicação de 
Súmula vinculante inconstitucional: forma de controle de constitucionalidade e crise de legitimidade

princípios e formação de precedentes, onde sua limitação estaria apenas no direito costumeiro e na jurisprudência já existente, consistentes na revelação do Direito por outros magistrados.

No que tange às diferenças filosóficas, transcreve-se a lição de Flávio Luís Oliveira e Nilson Tadeu Reis Campos Silva, ipsis litteris:

\begin{abstract}
O que nos parece relevante sublinhar é que o pomo de discórdia que separou esses primos-irmãos não radica em questão jurídica, mas, sim, filosófica, quando não ideológica: enquanto os integrantes da família do common law partem pragmaticamente da principiologia jurídica para dirimir conflitos, os da civil law adotam como ponto de partida o positivismo jurídico com o mesmo desiderato.

Ou seja, no common law, princípios legais são extraídos pelo Judiciário de decisões antecedentes, e no civil law aplica-se à situação fática submetida à decisão princípios positivados explícita ou implicitamente.

Tem-se, pois, que o divisor de águas das duas famílias do Direito queda em questão meramente filosófica: a opção ôntica de uma, e a deôntica doutra, o que não as fazem, contudo, inconciliáveis, como ver-se-á, posto que tanto substancialismo quanto procedimentalismo são, no fundo, visões éticas e como tal conciliáveis. (OLIVEIRA; SILVA, 2009, p. 65).
\end{abstract}

Neste diapasão, Nelson Luis Santander e Alexandre Sormani sustentam que o sistema jurídico romanista "é genericamente conhecido como aquele baseado em preceitos expressos, v. g., as leis. A fixação de direitos subjetivos e a imposição de deveres são previstas pelas leis, sendo a fonte primária do direito por excelência". (SANTANDER; SORMANI, 2009, p. 18).

Por outro lado, o common law seria o sistema jurídico dos precedentes, o qual estaria em completo antagonismo ao sistema romanista ou continental.

Em que pese o entendimento de que estes dois sistemas jurídicos são incompatíveis, há de prevalecer o pensamento oposto, ou seja, o de que ambos são conciliáveis.

Se algum dia este distanciamento existiu, hoje se encontra em via de ser superado, haja vista que ambos os sistemas jurídicos mencionados caminham mais e mais para uma aproximação; exemplo deste fenômeno é a súmula vinculante, que possui grande conexão com o sistema anglo-americano (SANTANDER; SORMANI, 2009, p. 30).

Todavia, não se pode realizar uma aproximação indiscriminada, importando-se para o ordenamento jurídico brasileiro vários instrumentos e técnicas processuais sem que haja qualquer "maturação cultural que traga a identidade legitimadora de sua inserção no lócus 
brasileiro" (OLIVEIRA; SILVA, 2009, p. 76); o que tem acontecido, muitas vezes, sem qualquer acomodação filosófica ou legislativa.

Ainda neste tema, cabe mencionar o art. 896, § 5으, da Consolidação das Leis do Trabalho (CLT), o qual, segundo Lenio Luiz Streck contém expressamente uma forma de vinculação de súmulas: "Não é difícil perceber o caráter vinculante que foi atribuído às Súmulas do Tribunal Superior do Trabalho" (STRECK, 1998, p. 150-152).

Este doutrinador sustenta esta posição devido ao fato de que o relator de um Recurso de Revista possui, atualmente, poderes para negar seguimento a recurso contrário à Súmula de Jurisprudência Uniforme do Tribunal Superior do Trabalho, situação similar a que ocorre com o art. 557, caput, do Código de Processo Civil2.

Lenio Luiz Streck afirma que tanto o art. 896, § 5ㅇ, da CLT, quanto a Lei n. 8.038/90, que institui normas procedimentais para os processos que tramitam perante o Superior Tribunal de Justiça e o STF, seguem lógicas idênticas, "com exceção da circunstância de que o art. 38 desta não condiciona, para a admissão do recurso especial, a hipótese de que a matéria não contrarie Súmula do Superior Tribunal de Justiça" (STRECK, 1998, p. 150-151). Quanto à inconstitucionalidade desse tipo de norma Lenio Luiz Streck afirma, in verbis:

Ao conferir tamanhos poderes ao relator do recurso de revista, descaracteriza-se a forma colegiada da decisão, passando, 'ipso facto', a ser de cunho individual (monocrática). Como já referido anteriormente, o mais grave, porém, não reside no caráter monocrático da decisão advinda da faculdade prevista pelo § 50 do art. 896, mas, sim, na vinculariedade que se dá às Sumulas do Tribunal Superior do Trabalho. [...] Além de inconstitucional, por contrariedade ao art. 5ㅇ, incisos II e XXXV, da Constituição Federal, o dispositivo leva à eternização da Súmula. (STRECK, 1998, p. 151).

Diante dessa lição, verifica-se que o referido autor é um dos grandes opositores da súmula de efeito vinculante, não aceitando, nem mesmo, as súmulas impeditivas de recurso, alegando que as mesmas engessariam o Poder Judiciário e violariam o princípio da inafastabilidade do acesso à Justiça. Note-se, todavia, que Lenio Luiz Streck publicou essa obra antes da constitucionalização da súmula vinculante no Brasil.

2 Art. 557. O relator negará seguimento a recurso manifestamente inadmissível, improcedente, prejudicado ou em confronto com súmula ou com jurisprudência dominante do respectivo tribunal, do Supremo Tribunal Federal, ou de Tribunal Superior. (Redação dada pela Lei no 9.756, de 17.12.1998). 
De outro giro, frente a este brevíssimo escorço histórico, pode-se constatar que a introdução da súmula vinculante no ordenamento jurídico brasileiro é fruto de uma evolução lógica e gradual, iniciada com a súmula persuasiva, passando à súmula impeditiva de recursos, até chegar à súmula de efeito vinculante. A utilidade do instituto jurídico em questão poderá ser admirável, desde que os Ministros do STF o utilizem dentro dos parâmetros constitucionais e infraconstitucionais estabelecidos pelo Poder Legislativo.

Assim, em princípio, a introdução da súmula vinculante no ordenamento jurídico brasileiro se afigura totalmente constitucional, em que pesem posicionamentos em contrário. A súmula de efeito vinculante se presta a uniformizar a jurisprudência dos tribunais, o que demonstra que este instrumento jurídico se encontra comprometido com os princípios constitucionais da segurança jurídica, da isonomia e também com o princípio da celeridade processual (art. 5ㅇ, LXXVIII, CF), introduzido em nosso ordenamento pela EC $\mathrm{n}$. $45 / 2004$.

\section{Natureza Jurídica da Súmula Vinculante}

Quanto à natureza jurídica da súmula vinculante, têm-se três posicionamentos na doutrina: a) é um tertium genus, não é lei, não é produto da jurisdição, é algo diferente; b) é a expressão do exercício do Poder Legislativo pelo Poder Judiciário; c) é um ato normativo de cunho jurisdicional.

Como representante da primeira corrente tem-se Gevany Manoel dos Santos, o qual sustenta, in verbis:

Com a nova lei, o Supremo Tribunal Federal passou a exercer essa nova atribuição que tem força de 'quase lei'. Nisso ocorre certo desvio de competência judiciária e invasão do Poder Legislativo. Essa nova atribuição de poder à Suprema Corte a coloca como um auxiliar do Poder Legislativo para corrigir as leis deficientes editadas por ele. (SANTOS, 2008, p. 28).

Nota-se que o autor acima citado faz severas críticas ao instituto ora estudado, constatando a existência de um desvio de competência judiciária por parte do STF, dando azo a uma clara invasão de competências, embora não consiga definir de forma clara qual a natureza jurídica da súmula de efeito vinculante, atribuindo-lhe natureza de tertium genus. 
Em princípio não se pode falar em usurpação de competências, poderes ou funções, o que acarretaria a inconstitucionalidade do art. 103-A da Lei Maior, uma vez ser este decorrente do poder constituinte reformador, e, por via de consequência, implicaria a inconstitucionalidade da Lei $n$. 11.417/2006, pois ambos os dispositivos legais estariam em contrariedade com o poder constituinte originário, o qual sempre há de prevalecer quando se trata de cláusulas pétreas. Neste caso a ofensa seria, em tese, ao princípio da separação de poderes (art. 60, § 4으, III, CF $/ 88^{3}$ ).

Sustentando a natureza legislativa da súmula vinculante, posto que dotada de abstração, generalidade, coercibilidade e obrigatoriedade, tem-se José de Albuquerque Rocha, in verbis:

\begin{abstract}
Um enunciado prescritivo, como dissemos, se caracteriza justamente por esses dois elementos, ambos encontrados na disposição do artigo 103-A e seus parágrafos: (a) dirigir a conduta humana e (b) qualificá-la como obrigatória. Portanto, repetimos, a disposição do artigo 103-A e seus parágrafos concede poderes ao Supremo Tribunal Federal para editar enunciado de súmula prescritivo.

[...]

Desse modo, analisada a súmula vinculante à luz do critério da validade, conclui-se ser uma norma jurídica, ou seja, pertencente ao ordenamento jurídico, já que produzida por um órgão do sistema jurídico, o Supremo Tribunal Federal, e no exercício de poderes conferidos por uma norma superior do sistema, qual seja, a que resulta da interpretação do disposto no artigo 103-A da Constituição. (ROCHA, 2009, p. 14-15).
\end{abstract}

Embora reconheça que a súmula vinculante é norma jurídica pertencente ao ordenamento jurídico, José de Albuquerque Rocha (2009, p. 121) não reconhece sua validade, pois afirma estarem sendo violados com a sua adoção diversos princípios e normas constitucionais concretizadores do princípio democrático.

Referido autor reconhece que o instituto jurídico analisado é inconstitucional por invalidade, haja vista que o STF seria órgão constitucionalmente ilegítimo para elaborar normas jurídicas gerais e abstratas, veja-se:

Como o princípio democrático está incorporado à Constituição, o que Ihe qualifica como princípio jurídico, tornando-se elemento essencial no procedimento de produção das normas jurídicas, isto é, requisito imprescindível para a validade das normas jurídicas, sua não observância é violação de norma jurídica constitucional,

3 § 4. Não será objeto de deliberação a proposta de emenda tendente a abolir: [...] III - a separação dos Poderes. 
acarretando a invalidade por inconstitucionalidade da norma assim criada (ROCHA, 2009, p. 121).

Assim, a súmula vinculante padeceria dos vícios de invalidade material e de ilegitimidade, em razão da usurpação da competência de um "Poder" por outro.

Por sua vez, negando natureza de lei à súmula vinculante, tem-se Elival da Silva Ramos, o qual afirma que a súmula vinculante não representa um ato legislativo.

$\mathrm{O}$ autor mencionado defende que o instituto jurídico analisado seria produto do exercício de atividade normativa atípica por parte do STF, atividade cujo produto jamais poderia ser equiparado à lei, posto que hierarquicamente inferior a esta.

Assim, referido autor reconhece que o produto desta atividade atípica poderia ser comparado aos regulamentos de execução do Poder Executivo:

Importa, contudo, precisar melhor a natureza dos enunciados sumulares vinculativos. Não se trata aqui de ato legislativo, quer em sentido formal, quer em sentido material, por atuarem as súmulas em nível hierárquico inferior àquele em que se manifesta o exercício da função legislativa. (RAMOS, 2010, p. 297).

De fato, lei em sentido estrito seria apenas aquele ato normativo editado de acordo com processo legislativo preceituado pela Constituição Federal (do art. 61 ao 69 da CF/88), originado exclusivamente do Poder Legislativo, cujas características essenciais são a generalidade, impessoalidade e abstração; sendo que seus objetivos principais são promover a organização e paz social, além de regular situações futuras da vida comunitária.

Em contraponto, a súmula de efeito vinculante é fruto de deliberação do Poder Judiciário, mais especificamente do STF, é casuística, pois é instrumento jurídico criado com o fim de combater a multiplicação de processos idênticos surgidos no Pretório Excelso, além da avalanche processual que o atinge. É aplicável tanto a situações atuais (processos em andamento), quanto a situações futuras.

Ainda no que tange à natureza jurídica da súmula vinculante, Glauco Salomão Leite reconhece a edição de súmula vinculante como exercício típico da função jurisdicional, decorrente do dever do Pretório Excelso de uniformizar a jurisprudência a fim de promover a segurança jurídica, veja-se: 
Portanto, nos casos que servem de base para a construção da jurisprudência geradora da súmula vinculante, verificam-se todas as características fundamentais da função jurisdicional expostas por Cappelletti, não se podendo falar, dessa forma, que as súmulas são produto de atuação legislativa do Supremo Tribunal Federal. Consistem, em verdade, na generalização e obrigatoriedade de uma solução aplicada a uma série de casos semelhantes, resultado, como se disse, de atividade interpretativo-criadora inerente ao exercício da jurisdição constitucional, em cujo contexto o efeito vinculante das súmulas tem uma importante função harmonizadora da exegese jurídico-constitucional, dirimindo uma divergência judicial. Assumindo essa postura, não se vislumbra ofensa à separação dos poderes através das súmulas vinculantes, no sentido de que elas representariam uma usurpação das funções típicas do Poder Legislativo. (LEITE, 2007, p. 104).

Sem dúvida a súmula vinculante representa o legítimo exercício da jurisdição constitucional, porém esta assertiva somente continuará sendo verdadeira se os Ministros do Pretório Excelso ficarem adstritos ao regramento constitucional e infraconstitucional do instituto analisado. Os excessos não devem ser aceitos.

Notadamente este instrumento jurídico visa à uniformização de jurisprudência e promoção da celeridade processual, além do que tem o condão de atribuir efeito erga omnes às decisões tomadas em sede de controle concreto de constitucionalidade.

Ademais, a súmula de efeito vinculante caracteriza-se pela exigência da ocorrência de sucessivos casos idênticos, onde haja interpretações antagônicas da lei em face da Constituição, nas jurisdições ordinárias; e, ainda, conclama o STF para uma tomada de posição frente a estas interpretações divergentes. Este, por conseguinte, fixará a validade, interpretação prevalente e dimensão da eficácia da legislação infralegal em análise.

A súmula vinculante deve ser construída através da elaboração de um ato de cunho normativo geral e abstrato objetivando dar segurança jurídica (previsibilidade da prestação jurisdicional) aos jurisdicionados.

Assim, embora a súmula vinculante esteja atrelada ao exercício da jurisdição constitucional, devem-se combater os abusos, evitando-se que os ministros do STF legislem se valendo do pretexto de uniformizar a jurisprudência e promover a segurança jurídica. Nesta esteira, fazendo paralelo com os Assentos do Direito Português, leciona J. J. Gomes Canotilho:

Uma problemática semelhante à do assento suscita-se hoje no Brasil, a propósito do chamado efeito vinculante das decisões judiciais ou súmulas vinculantes. Tratase de uma proposta feita em sede de revisão constitucional e que se destina a descongestionar os processos junto ao STF e a assegurar alguma uniformização da 
jurisprudência. De novo se coloca a questão central destas decisões: se aspirarem a constituir uma forma de legislatio com efeito vinculante geral e obrigatório, é difícil compatibilizá-las (salvo credencial constitucional expressa) com o princípio da separação dos poderes. Se elas forem apenas vinculantes para os tribunais integrantes da mesma ordem e susceptíveis de revisão (nos termos fixados em lei) a sua configuração ainda é a de um acto de jurisdição destinado a dizer-se o direito e assegurar uma tendencial uniformização. (CANOTILHO, 2001, p. 906).

A salutar advertência de J. J. Gomes Canotilho não deve ser ignorada, haja vista que uma fúria sumular pode ter o condão de abalar a estrutura da democracia, devido à indesejável sobreposição de funções.

Como se vê, não há quem negue a natureza de ato normativo lato sensu da súmula vinculante, por isso nada obsta que a mesma seja impugnada por meio de ADI. Por conseguinte, quer a reconheçam como mero ato normativo jurisdicional, quer a classifiquem como norma jurídica, em qualquer dessas hipóteses o art. 103, caput, da Constituição Federal terá incidência.

\section{Invasão de competência: utilização de Súmula Vinculante para legislar}

Por sua vez, Marcelo Neves nos ensina que o corolário da "divisão de poderes" é a separação entre política e administração; o referido autor sustenta que: "A ausência ou deformação do princípio da 'divisão de poderes' leva à desdiferenciação das esferas de vida (politização abrangente) e tem-se demonstrado incompatível com a complexidade da sociedade atual". (NEVES, 2007, p. 81).

Em que pesem os entendimentos de que a súmula vinculante é a típica expressão da função jurisdicional, sendo, então, constitucional, a utilização que o STF vem fazendo dela tem lhe tornado um instrumento de afronta à Lei Maior, uma vez que a tênue linha que estabelece a separação dos Poderes tem sido continuamente transposta.

Assim, se pode afirmar que o Guardião da Constituição tem sinalizado que tenderá a utilizar um instrumento previsto na Lei Fundamental para desrespeitá-la. Com efeito, vejam-se dois exemplos claros, as Súmulas Vinculantes n. 05 e 11, in verbis:

Súmula Vinculante n. o 5: A falta de defesa técnica por advogado no processo administrativo disciplinar não ofende a constituição.

Súmula Vinculante n. 11: Só é lícito o uso de algemas em casos de resistência e de fundado receio de fuga ou de perigo à integridade física própria ou alheia, por 
parte do preso ou de terceiros, justificada a excepcionalidade por escrito, sob pena de responsabilidade disciplinar, civil e penal do agente ou da autoridade e de nulidade da prisão ou do ato processual a que se refere, sem prejuízo da responsabilidade civil do estado.

Diante desses exemplos, nota-se que o STF editou súmulas sobre questões que não possuem lei versando a seu respeito, desrespeitando de forma frontal um dos objetivos da súmula vinculante, qual seja: “A súmula terá por objetivo a validade, a interpretação e a eficácia de normas determinadas" 4 .

No que tange à Súmula Vinculante n. 05 do STF, cabe ressaltar que a própria Constituição Federal considera o advogado essencial à administração da Justiça ${ }^{5}$, sendo que a lei que regula o processo administrativo no âmbito da Administração Pública Federal, Lei n. 9.784/99, não dispensa a atuação de advogado em procedimento administrativo disciplinar, sendo que o Superior Tribunal de Justiça (STJ) possui, inclusive, súmula persuasiva a respeito, a Súmula n. 343, a qual contém posicionamento diametralmente oposto ao adotado pelo STF, veja-se: "É obrigatória a presença de advogado em todas as fases do processo administrativo disciplinar".

Neste ponto já se constata o desrespeito a alguns princípios constitucionais, quais sejam: a) essencialidade do advogado; b) devido processo legal (e seus derivados: contraditório e ampla defesa); e, c) legalidade.

O Estatuto da Advocacia, Lei n. 8.906/94, também preceitua a essencialidade do advogado em seu art. 2ํ, caput, e $\S 1^{0^{6}}$. Logo, não há lei dispensando a promoção de defesa técnica por advogado, por isso a súmula não analisou a validade ou eficácia de norma nesse sentido, tampouco lhe deu uma interpretação conforme a Constituição. Essa súmula nasceu de um procedimento similar ao do processo legislativo, ou seja, o Pretório Excelso legislou neste caso.

4 Art. 103-A [...] § 10 A súmula terá por objetivo a validade, a interpretação e a eficácia de normas determinadas, acerca das quais haja controvérsia atual entre órgãos judiciários ou entre esses e a administração pública que acarrete grave insegurança jurídica e relevante multiplicação de processos sobre questão idêntica.

5 Art. 133. O advogado é essencial à administração da Justiça, sendo inviolável por seus atos e manifestações no exercício da profissão, nos limites da lei.

6 Art. 2‥ O advogado é indispensável à administração da justiça. § 1‥ No seu ministério privado, o advogado presta serviço público e exerce função social. 
Quanto à Súmula Vinculante n. 11, vê-se que a mesma nasceu da necessidade, constatada pelo STF, de regulamentar o uso de algemas, pois diversos abusos vinham ocorrendo. Por não haver lei regulando tal situação o STF editou a súmula em comento.

Neste caso também o STF laborou como se legislador fosse. Para se analisar esta questão, recorre-se a Miguel Reale e à sua Teoria Tridimensional do Direito.

Para que uma norma jurídica surja é necessária a junção de três elementos, quais sejam: fato, valor e norma.

O fato, nada mais é que um fato social que passa a ter relevância jurídica dentro de uma determinada sociedade; o valor está associado à valoração de um fato, ação realizada pelo legislador quando da propositura, discussão e aprovação das normas jurídicas, onde se avalia a influência de certa conduta na sociedade e como regulá-la de forma a manter a ordem social. A norma é o produto de um fato valorado, que adquire o poder de coerção social (REALE, 2003, p. 64-68).

Diante disso, inexoravelmente se conclui que o Pretório Excelso realizou típica ação de legislador, ou seja, usurpou a competência do Poder Legislativo, posto que constatou a existência de um fato social relevante, exerceu sobre ele um juízo de valor, e depois disso editou uma "norma jurídica" (leia-se: súmula vinculante) dotada de generalidade e abstração para regulamentar o uso das algemas pelas autoridades públicas.

Em relação à súmula vinculante n. 11, André Ramos Tavares tece uma série de críticas, as quais se transcrevem, ipsis litteris:

Esta súmula vinculante demonstra, novamente, o desrespeito do STF aos requisitos constitucionais mínimos para a aprovação desta medida. Isso porque o art. 103-A da Constituição é expresso ao determinar a necessidade de "reiteradas decisões" sobre matéria constitucional para a edição de súmula vinculante que, como enfatizei ao longo deste estudo, é uma exigência coerente com a necessidade de profundo amadurecimento prévio à deliberação favorável à edição de uma súmula com efeito vinculante.

Nesse sentido, inexistiram no Supremo Tribunal Federal reiteradas decisões sobre a questão da limitação do uso de algemas por agentes ou autoridades policiais, que pudessem justificar a aprovação de referida súmula vinculante, comprovando a violação ao dispositivo constitucional referido. O STF tanto tem desrespeitado o formalismo inerente a uma decisão desse quilate como também os próprios pressupostos materiais que deveriam estar presentes para que se editasse legitimamente uma súmula de efeito vinculante. (grifo nosso). (TAVARES, 2009, p. 155-156). 
A Súmula Vinculante vale para todos (generalidade) e obriga a todos (coerção, abstratividade). Logo, da forma como vem sendo utilizada pelo Supremo Tribunal Federal, não perde em nada para a lei, são equivalentes.

José de Albuquerque Rocha, totalmente contrário à adoção da súmula vinculante, retrata de forma didática a inconstitucionalidade deste instituto, a qual, no seu entender, ocorre devido à usurpação da competência de um Poder por outro. A esse respeito, veja-se:

\begin{abstract}
Por conseguinte, o art. 103-A, ao conferir competência ao Supremo Tribunal Federal para produzir normas gerais e abstratas mediante a emissão de enunciados de súmula vinculante, infringe o mencionado art. 5o, II, da Constituição, que reserva a matéria à competência absoluta do legislador democrático, o que configura sua inconstitucionalidade por incompetência material, isto é, por praticar ato normativo de caráter geral e abstrato sem a necessária competência material, eis que reservada a competência do legislador democrático. Em se tratando de incompetência da autoridade criadora do ato, em razão da matéria, o vício invalida de inconstitucionalidade o próprio ato normativo que tem por objeto a matéria reservada ao legislador democrático e, em consequência, o texto legislativo e as normas dele derivadas. Quanto à súmula vinculante, se o ato que confere poderes ao Supremo Tribunal Federal para editar enunciados de súmula vinculante é inválido por inconstitucionalidade, segue-se, logicamente, que o Supremo Tribunal Federal carece de competência para emitir súmulas vinculantes, pelo que são nulos por inconstitucionalidade os atos produtores de súmula vinculante, os enunciados sumulares e as normas deles derivadas. (ROCHA, 2009, p. 116).
\end{abstract}

Entretanto, não se pode ir tão longe, pois este trabalho tem como pressuposto a constitucionalidade do instituto da súmula de efeito vinculante; mas obviamente parte da conclusão do referido doutrinador procede, haja vista que a partir do momento em que os ministros do STF se auto-elevam à posição de legisladores, perdem toda a sua legitimidade, e, por conseguinte, o ato normativo decorrente dessa conduta inconstitucional, é também inconstitucional, ou seja, a súmula vinculante editada em contraposição aos ditames constitucionais já nasce maculada pela nulidade $a b$ ovo.

Assim, se pode ter súmulas vinculantes formalmente inconstitucionais e súmulas vinculantes materialmente constitucionais.

As primeiras ocorrem devido à inobservância do processo de elaboração previsto constitucionalmente, ou seja, são aquelas portadoras de vício de iniciativa, votação ou que não atenderam aos pressupostos para a proposta de edição ou revisão de súmula vinculante, neste ponto destacam-se as reiteradas decisões do STF sobre matéria constitucional num mesmo sentido; a necessidade de segurança jurídica, somente atingida 
com a aplicação do princípio da isonomia nos julgamentos; e a multiplicação de processos sobre o mesmo tema.

Já a inconstitucionalidade material da súmula de efeito vinculante ocorre quando o conteúdo desta é inconstitucional, como acima exemplificado com a Súmula Vinculante n. 5.

\title{
5 Súmula Vinculante Inconstitucional: formas de impugnação (ADPF, RECLAMAÇÃo OU ADI)
}

Marco Antonio Botto Muscari não concorda com a possibilidade de edição de súmulas vinculantes inconstitucionais pelo STF. Fundamenta este posicionamento no fato de que este órgão é o principal guardião da Constituição Federal de 1988, por isso não poderia emitir decisões vinculativas que afrontem à Lei Maior. Ademais, o supracitado autor sustenta que:

\begin{abstract}
Ainda que se admitisse a hipótese de haver súmula vinculante inconstitucional, caberia ao Supremo Tribunal Federal julgar a ação direta respectiva. E convenhamos, essa ação nasceria fadada ao insucesso, na medida em que, ao adotarem a tese sumulada, os integrantes do Pretório Excelso obviamente julgaram-na (ainda que de forma implícita) compatível com a Carta Magna. (MUSCARI, 1999, p. 94).
\end{abstract}

Data maxima venia, não se pode adotar tal posicionamento, pois com o advento da Lei n. 11.417/2006, principalmente diante do art. 3 o,$\S 20$ da referida lei $^{7}$, onde se admite no processo de edição, revisão e cancelamento de súmula vinculante a presença dos amici curiae, verifica-se que o STF não mais ficará encerrado em uma redoma de vidro, mas, sim, deverá ouvir, caso entender necessário e oportuno, a sociedade organizada.

De outro giro, embora os atos do Poder Público gozem de presunção de legalidade e legitimidade, não se poderiam elevar os ministros do Pretório Excelso ao posto da divindade, atribuindo-se a eles os atributos da infalibilidade e da inerrância.

Caso contrário, estar-se-ia em um impasse, posto que a súmula vinculante seria válida em razão da autoridade que a editou, e, não, em razão de seu conteúdo.

\footnotetext{
${ }^{7} \S 2^{\circ}$ No procedimento de edição, revisão ou cancelamento de enunciado da súmula vinculante, o relator poderá admitir, por decisão irrecorrível, a manifestação de terceiros na questão, nos termos do Regimento Interno do Supremo Tribunal Federal.
} 
Daí surgem dois questionamentos: a) nosso sistema legal estaria retornando a um positivismo exacerbado, ou pior, a um positivismo judiciário; ou, b) de onde os ministros do STF retirariam legitimidade para editar atos de cunho normativo livres de qualquer controle de constitucionalidade.

A Arguição de Descumprimento de Preceito Fundamental (ADPF) em princípio não seria cabível para impugnar súmula vinculante inconstitucional, haja vista a sua subsidiariedade, a qual se encontra prevista no art. 4으, § 1으, da Lei n. 9.882/1999 ${ }^{8}$.

Por sua vez, a Reclamação tem aplicação específica definida na CF/88 e na Lei $\mathrm{n}$. 11.417/2006, por isso não teria o condão de impugnar súmulas vinculantes inconstitucionais. Serve tão somente para combater decisão judicial ou ato administrativo que: a) contrarie enunciado de súmula vinculante; b) negue vigência a esta; ou, c) aplique-a de forma indevida.

Com efeito, o art. 70, caput, e o § 1으, da lei já mencionada preveem que a Reclamação possui a característica da simultaneidade, além da característica de último recurso (ultima ratio) no caso de impugnação de atos comissivos ou omissivos da Administração Pública.

Logo, a Reclamação não é o instrumento adequado ao exercício de controle de constitucionalidade neste caso, haja vista existir instrumento mais adequado e efetivo, qual seja: a Ação Direta de Inconstitucionalidade - ADI.

A adoção do entendimento de que a ADI é cabível para atacar súmulas vinculantes inconstitucionais é plenamente defensável e adequada, pois, caso contrário, não haverá ao alcance dos jurisdicionados nenhum outro instrumento processual apto para atacar súmulas de efeito vinculante flagrantemente inconstitucionais.

Embora a razoabilidade do entendimento adotado acima, o jurista Marco Antonio Botto Muscari defende tese oposta, a qual se transcreve in verbis: "Em suma, caso acabe prevalecendo a diretriz aprovada pela Câmara Alta, não haverá lugar para a ação direta de inconstitucionalidade tendo por objeto a súmula vinculante" (MUSCARI, 1999, p. 94).

Todavia, justiça seja feita, apenas em uma hipótese o doutrinador supracitado acata o posicionamento ora esposado, veja-se: "Se o panorama mudar, permitindo-se que

\footnotetext{
8 § 1 Não será admitida a arguição de descumprimento de preceito fundamental quando houver qualquer outro meio eficaz de sanar a lesividade. 
também os Tribunais Superiores (STJ, TST, TSE e STM) emitam súmula vinculante, aí sim, poder-se-á admitir a ação direta de inconstitucionalidade da súmula" (MUSCARI, 1999, p.94).

Em tempo, cabe ressaltar que a EC n. 45/2004, tampouco a Lei n. 11.417/2006, atribuiu competência para a edição de súmulas vinculantes aos Tribunais Superiores, com o quê pode-se concluir que a única hipótese vislumbrada por Marco Antonio Botto Muscari está meramente no plano teórico.

Porém, o doutrinador supracitado se esquece de que os ministros do Supremo Tribunal Federal podem rever seus posicionamentos em sede de ADI, caso seja questionada a inconstitucionalidade de uma súmula de efeito vinculante.

Ademais, a composição do Pretório Excelso pode mudar no espaço de tempo contido entre a edição de uma súmula e o ajuizamento de uma ADI.

Pedro Lenza também, porém por outros motivos, entende inadmissível a adoção de ADI contra súmula vinculante; este ensina que a "súmula de jurisprudência não possui o grau de normatividade qualificada, não podendo, portanto, ser questionada perante o STF através de controle concentrado" (LENZA, 2008, p. 159).

Todavia, se equivoca Pedro Lenza neste ponto, pois a generalidade e a abstração são as formas pelas quais o Pretório Excelso faz com que suas decisões transcendam de um caso concreto específico para todos os demais casos semelhantes. Não obstante, se transcreve a seguir a lição do referido autor, veja-se:

\footnotetext{
Assim, tendo em vista o fato de a súmula não ser marcada pela generalidade e abstração, diferentemente do que acontece com as leis, não se pode aceitar a técnica do 'controle de constitucionalidade' de súmula, mesmo no caso de súmula vinculante. $O$ que existe é um procedimento de revisão pelo qual se poderá cancelar a súmula. $O$ cancelamento desta significará a não mais aplicação do entendimento que vigorava. Neste caso, naturalmente, essa nova posição produzirá as suas conseqüências a partir do novo entendimento, vinculando os demais órgãos do Poder Judiciário e a administração pública direta e indireta, nas esferas federal, estadual e municipal. (LENZA, 2008, p. 159-160).
}

Note-se que a utilização da $A D I$, em detrimento de um mero requerimento de revisão ou cancelamento de súmula vinculante, tem uma finalidade muito importante, qual seja: tornar a súmula atacada nula desde o seu nascimento, cancelando todos os seus efeitos, uma vez que inconstitucional. 
Em sentido contrário a Pedro Lenza e a Marco Antonio Botto Muscari, tem-se Rodolfo de Camargo Mancuso, o qual esposa entendimento semelhante ao ora defendido neste trabalho, afirmando que:

Por fim, considere-se que até mesmo norma inserida pelo constituinte revisor pode vir a ter sua constitucionalidade sindicada (STF: RDA 191/214; 198/123), de sorte que não poderia a súmula vinculante constituir-se em exceção isolada do contexto geral (MANCUSO, 2007, p. 369).

Rodolfo de Camargo Mancuso ensina que a súmula vinculante deverá ser objeto de controle de constitucionalidade, porém alerta para o fato de que caberá ao Pretório Excelso aceitar, ou não, a incidência deste controle. Tudo dependerá de o STF estender, ou não, às súmulas vinculantes o posicionamento que tem quanto às súmulas persuasivas, qual seja: de que elas não são objeto de controle de constitucionalidade. Aproveita-se para transcrever mais acerca de seu posicionamento, in verbis:

\begin{abstract}
A conformidade com a Constituição é uma condição de validade e eficácia de todos os atos estatais em sentido largo, e por isso sujeitam-se ao controle de constitucionalidade, na dupla via direta e incidental, as normas legais e os atos normativos, isto é, os 'produtos finais' do Estado-legislador e do Estadoadministrador. A súmula vinculante é produto final, potencializado, do Estado-juiz, participando, a um tempo, da natureza da 'lei' - enquanto enunciado geral, abstrato, impessoal e impositivo - e dos 'atos normativos', haja vista sua função paradigmática, pan-processual, voltada à resolução isonômica das lides, projetando efeitos diretos e reflexos. [...] Assim como as decisões de mérito, transitada em julgado, quando eivadas de vícios graves e insanáveis sujeitam-se a serem desconstituídas via ação rescisória (CPC, art. 485); assim como uma resolução do Conselho Nacional de Justiça - órgão integrante do Judiciário: art. 92, I-A - pode ter sua constitucionalidade questionada; assim como uma norma constitucional derivada pode ser declarada inconstitucional (JSTF 185/69), também uma súmula vinculante do STF, uma vez emitida em desconformidade com alguns de seus pressupostos constitutivos, [...] poderá ter sua constitucionalidade sindicada. (MANCUSO, 2007, p. 369).
\end{abstract}

Portanto, verifica-se que a revisão ou cancelamento de uma súmula vinculante terá efeito apenas ex nunc, ou seja, ocorreria como se aquela tivesse sido apenas revogada ou modificada, sem irradiar seus efeitos às relações jurídicas realizadas no passado sob sua égide.

Por outro lado, o reconhecimento da inconstitucionalidade através de ADI traria efeitos ex tunc à decisão tomada, a não ser que o STF modulasse os efeitos desse decisum. 
Súmula vinculante inconstitucional: forma de controle de constitucionalidade e crise de legitimidade

Todavia, não se pode dizer, conforme sustenta José Anchieta da Silva, que a súmula em questão engessaria o Poder Judiciário, pois necessariamente deverá ser aplicado ao nosso Direito o instituto do distinguishing. Não obstante, transcreve-se o ensino desse autor, in verbis:

\begin{abstract}
A admissão da súmula de efeito vinculante amplo impõe admitir-se o inadmissível. Corresponde ela o admitir que todos os juízes terão que pensar e que concordar, previamente, com todas as decisões emanadas do Supremo Tribunal Federal, no que vier a ser estabelecido como súmula de efeito vinculante. É o engessamento prévio de todo o Judiciário sobre o compreendido na súmula. [...] Violenta-se assim a consciência e a individualidade do julgador togado, pois ao juiz não se pode impor um alinhamento definitivo com o pensamento da Suprema Corte, sem que tal se dê, nos limites da lide, observado o alcance da relatividade e da individualidade de cada processo. (SILVA, 1998, p. 28-29).
\end{abstract}

A súmula vinculante exige agora maior criatividade e poder de argumentação da parte dos advogados, pois para que um caso sub judice não seja julgado conforme determinada súmula obrigatória, o causídico terá que realizar todo um esforço argumentativo a fim de demonstrar que aquela súmula não se aplica àquele caso em especial. Essa é a lição de José Anchieta da Silva, a qual se transcreve:

No direito americano, a empreitada processual que tem por finalidade evitar a aplicação do 'stare decisis' sobre determinado caso é o 'distinguishing' ou, em português, o distínguo. A demonstração da existência do distínguo ou da distinção entre o caso em pauta e a situação cristalizada por um 'stare decisis' é tarefa a ser levada, a termo e a cabo, pelos advogados patrocinadores do caso em concreto. (SILVA, 1998, p. 63).

Nisso consiste o instituto do distinguishing, que, conforme nosso entendimento, deverá ser importado ao direito brasileiro pelos advogados e juízes, os quais quando entenderem que o caso a eles submetido é peculiar, deverão alegar a singularidade do mesmo e, de forma fundamentada, indicar qual a norma jurídica aplicável ao caso. Com efeito, Rodolfo de Camargo Mancuso compartilha desse posicionamento, veja-se:

Parecendo ao juiz que determinada súmula vinculativa não rege ou não abrange o objeto litigioso do processo, poderá, 'fundamentadamente', deixar de aplicá-la, em processo exegético, portanto, semelhante ao que ocorre quando uma norma legal é invocada nos autos, mas em verdade não se aplica ao caso vertente. De resto, mesmo no regime da 'common law', pode o juiz demonstrar que o caso concreto não é 'precisely similar' ao precedente judiciário (a técnica do 'distinguishing', que 
pode autorizar o 'overruling', ou seja, o descarte do precedente jurisprudencial). (MANCUSO, 2007, p. 354).

Os juízes somente ficarão amordaçados ou engessados se quiserem, ou seja, por pura acomodação, pois qualquer magistrado não entendendo aplicável determinada súmula ao caso que está a julgar poderá julgar de forma diversa, porém fundamentada, e nestes casos de forma muito mais exaustiva, para evitar que as instâncias superiores, quando provocadas, se deixem seduzir pela facilidade mecânica da simples aplicação de uma súmula vinculante. Aqui cabe citar ensinamento de Rodolfo de Camargo Mancuso, in verbis:

\begin{abstract}
A utilização da súmula vinculativa não compromete nem dispensa a necessária motivação/fundamentação das decisões judiciais, quesito esse que, de resto, é pressuposto de validade do provimento judicial (CF, art. 93, IX). O juiz decide sobre o alegado e provado, nos termos do pedido. [...] Ao invocar a súmula para decidir o caso concreto, o juiz fundamentará tal aplicação: primeiro, buscando esclarecer o seu próprio enunciado (=extensão e compreensão); segundo, demonstrando que o objeto litigioso do processo enquadra-se na indigitada súmula. (MANCUSO, 2007, p. 368).
\end{abstract}

A contrario sensu, o juiz deverá adotar o mesmo procedimento para não aplicar as súmulas vinculantes.

\title{
Conclusão
}

A súmula de efeito vinculante, em tese, não representaria o exercício de função legislativa pelo Poder Judiciário, tampouco seria inconstitucional, desde que utilizada de acordo com os ditames constitucionais. Todavia, a forma como o STF vem utilizando a mesma tem lhe transformado em instrumento de afronta à Constituição Federal e de usurpação de funções do Poder Legislativo pelo Poder Judiciário.

Não se pode admitir que onze Ministros do STF usurpem a função de todo o Congresso Nacional, o ativismo judicial não pode chegar a estes extremos, sob pena de insegurança jurídica. O Brasil é um Estado Democrático de Direito, vigora o preceito de que o exercício da soberania popular é levado a efeito por meio da representação popular, a qual é atribuída a deputados e senadores no âmbito federal.

Sem dúvida, desde que observados os preceitos constitucionais, a súmula de efeito vinculante é constitucional, uma vez que este dever de uniformizar jurisprudência, de 
isonomia e de celeridade processual foram agasalhados pela norma constitucional e atribuídos ao Poder Judiciário, sobretudo ao STF.

Todavia, quando o Pretório Excelso elabora súmulas vinculantes de forma imediatista, sem preencher os requisitos constitucionais e legais, foge à sua competência e se autoproclama legislador, padecendo seus atos, daí em diante, de legitimidade.

Com efeito, também não se pode admitir que a forma como as súmulas vinculantes são elaboradas, e seu conteúdo, fiquem livres de qualquer forma de controle. Entendemos que, embora o instituto da súmula vinculante seja constitucional o seu produto final, a súmula de efeito vinculante, pode, sim, padecer de vícios de inconstitucionalidade formal e material.

E diante desta constatação, verifica-se que caso prevalecesse o entendimento de que as súmulas vinculantes uma vez editadas seriam intangíveis, posicionamento inclusive adotado por Marco Antonio Botto Muscari, não haveria forma de controle destes atos ilegítimos e inconstitucionais; por isso entendemos, a despeito do que defende este doutrinador, que as súmulas de efeito vinculante, por serem um ato essencialmente normativo, embora não possam ser equiparados às leis em sentido estrito, podem ser objeto de impugnação por meio de ADI.

Admitir que a súmula vinculante editada pelo Pretório Excelso seja eterna e inatacável é aceitar que o STF, representante do Poder Judiciário, está acima dos demais poderes, o que não se afigura como uma interpretação fiel à Constituição Federal.

O STF faz o controle de constitucionalidade repressivo, ou seja, afirma quando uma norma está em desconformidade com a Constituição Federal, o que não significa que por ter o Pretório Excelso editado uma súmula vinculante inconstitucional esta passa a ser constitucional.

Quando ocorrer da edição de uma súmula vinculante inconstitucional, se já não ocorreu, o STF deverá ser alertado, e a forma de fazer isso é por meio de ADI, posto que este instrumento constitucional-processual tem consequências mais amplas que o mero pedido de revisão de súmulas vinculantes, previsto no art. 103-A, § 2으, da CF.

A declaração da inconstitucionalidade de um ato normativo tem efeito ex tunc, a não ser que o STF module os efeitos de sua decisão, ao passo que a revisão ou cancelamento de uma súmula vinculante inconstitucional tem apenas efeito ex nunc. 
Diante disso, defendemos a aplicação do instrumento processual mais eficaz para sanar o vício de inconstitucionalidade, qual seja: a ADI.

Portanto, a súmula vinculante não é inatingível, não possui presunção absoluta de constitucionalidade e não pode se tornar em instrumento para que o Supremo Tribunal Federal passe a legislar.

\section{Referências}

CANOTILHO, J. J. Gomes. Direito Constitucional e Teoria da Constituição. 4. ed. Coimbra: Almedina, 2001.

LEITE, Glauco Salomão. Súmula Vinculante e Jurisdição Constitucional Brasileira. Rio de Janeiro: Forense, 2007.

LENZA, Pedro. Direito Constitucional Esquematizado. 12. ed. rev. e atual. São Paulo: Saraiva, 2008.

LOR, Encarnacion Alfonso. Súmula Vinculante e Repercussão Geral: novos institutos de direito processual constitucional. São Paulo: Editora Revista dos Tribunais, 2009.

MANCUSO, Rodolfo de Camargo. Divergência Jurisprudencial e Súmula Vinculante. 3. ed. rev. atual. e ampl. São Paulo: Revista dos Tribunais, 2007.

MONTESQUIEU. Do Espirito das Leis. São Paulo: Martin Claret, 2007.

MUSCARI, Marco Antonio Botto. Súmula Vinculante. São Paulo: Editora Juarez de Oliveira, 1999.

NEVES, Marcelo. A constitucionalização simbólica. São Paulo: Martins Fontes, 2007.

OLIVEIRA, Flávio Luís; SILVA, Nilson Tadeu Reis Campos. Ouvir o outro: um pensar sobre um código de legitimação. Revista Novatio luris, ano II, n. 4, dez. 2009.

RAMOS, Elival da Silva. Ativismo Judicial: Parâmetros Dogmáticos. São Paulo: Saraiva, 2010.

REALE, Miguel. Lições Preliminares de Direito. 27. ed. São Paulo: Saraiva, 2003.

ROCHA, José de Albuquerque. Súmula Vinculante e Democracia. São Paulo: Atlas, 2009. 
SANTANDER, Nelson Luis; SORMANI, Alexandre. Súmula Vinculante: um estudo à luz da Emenda Constitucional 45, de 08.12.2004.2. ed. rev. e ampliada de acordo com a Lei 11.417, de 19.12.2006. Curitiba: Juruá Editora, 2009.

SANTOS, Gevany Manoel dos. Súmula Vinculante e Reclamação: Forma de Aplicação. São Paulo: LTr, 2008.

SILVA, José Afonso da. Aplicabilidade das Normas Constitucionais. 7. ed. São Paulo: Ed. Malheiros, 2009.

SILVA, José Anchieta. Súmula de Efeito Vinculante Amplo no Direito Brasileiro. 1. ed. Del Rey: Belo Horizonte, 1998.

STRECK, Lenio Luiz. Súmulas no Direito Brasileiro: Eficácia, Poder e Função. 2. ed. rev. e atual. Porto Alegre: Livraria do Advogado, 1998.

TAVARES, André Ramos. Nova Lei da Súmula Vinculante: Estudos e Comentários à Lei 11.417, de 19.12.2006. 3. ed. São Paulo: Método, 2009.

Artigo recebido em 29/12/2011 e aprovado para publicação em 08/03/2012. 
